\title{
Discussion: Creep improvement factors for vibro-replacement design
}

Brian G. Sexton BE, PhD, MIEI

Geotechnical Engineer, AGL Consulting, Sandyford, Dublin, Ireland

Vinayagamoothy Sivakumar MSC, DIC, PhD, PGCHET

Reader, School of Natural and Built Environment, Queens University of

Belfast, Belfast, Northern Ireland

Bryan A. McCabe BA, BAl, PhD, CEng, Eurlng, FIEI

Lecturer, College of Engineering and Informatics, National University of

Ireland, Galway, Ireland (corresponding author: bryan.mccabe@nuigalway.ie)
Richard Pugh BSC, MSC, PhD, CEng, FICE

Consulting Geotechnical Engineer, Cranbrook, UK

(Orcid:0000-0001-8164-4403)

\section{Contribution by Richard Pugh}

Sexton et al. (2017) have used the results of advanced numerical modelling of stone columns in soft cohesive soils to develop an empirical design approach which, for the first time, enables creep to be incorporated into the routine design of stone columns for settlement reduction. This approach (Equation 15) relates the ratio between the creep settlement-improvement factor $\left(n_{\text {creep }}\right)$ and the primary settlement-improvement factor ( $\left.n_{\text {primary }}\right)$ to the reciprocal area replacement ratio and is proposed for use by practising engineers in tandem with a pre-existing primary settlementimprovement design method.

Pugh (2017, 2018) proposed a practical upper-bound relationship between primary settlement reduction $\left(S_{\mathrm{r}(\text { primary })}=\right.$ $\left.1-1 / n_{\text {primary }}\right)$ and stone replacement $\left(A_{\mathrm{r}}-\right.$ also area replacement ratio) for stone-column groups installed in very soft clay. This relationship is shown in Figure 23 together with the theoretical relationship of Priebe (1995, with a stone-friction angle $\left(\phi^{\prime}\right)$ of $\left.40^{\circ}\right)$, which is commonly used in practice. Pugh (2018) also proposed that, for practical design purposes, creep settlement reduction should be assumed not to exceed $50 \%$ of the practical upper-bound primary settlement reduction. This latter proposal was inferred by Pugh (2018) from the discussion of Pugh (2017) by McCabe and Sexton (Pugh et al., 2017) and the results of numerical modelling of primary and creep settlement reduction for stone columns in soft clay presented by Sexton and McCabe (2016).

Figure 23 presents creep settlement reductions $\left(S_{\mathrm{r}(\text { creep })}=\right.$ $1-1 / n_{\text {creep }}$ ) derived using Sexton et al.'s (2017) empirical Equation 15 in combination with both the theoretical primary settlement reduction of Priebe (1995) and the practical upperbound primary settlement reduction of Pugh (2018) indicating that, as noted by McCabe and Sexton (Pugh et al., 2017) and Sexton et al. (2017), the efficiency of stone-column groups with respect to creep settlement reduction is much reduced in comparison to primary settlement reduction. Figure 23 shows that the practical upper-bound creep settlement reduction corresponds to the theoretical value at $5 \%$ stone replacement, with the ratio $S_{\mathrm{r} \text { (creep) }} / S_{\mathrm{r} \text { (primary) }}$ being $50 \%$. This ratio, however, decreases to $40 \%$ at $15 \%$ stone replacement, at which point the practical creep settlement reduction equates to the practical lower bound (Pugh, 2017, 2018); this being the settlement reduction that could be achieved by simply reducing the thickness of compressible clay in the same proportion as the required settlement reduction and replacing it with the same proportion of incompressible stone.

Comparison of the predicted creep settlement reductions with the practical lower bound (Figure 23) indicates that, with respect to creep, stone columns provide little in the way of mechanical advantage over excavation and replacement, either in theory or practice. This limited practical creep settlement reduction is considered to be entirely consistent with the observations of Pugh (2017) based on the results of long-term case histories (see also Pugh in the discussion paper Pugh et al. (2017)) and therefore to provide practical validation of Sexton et al.'s (2017) empirical relationship between creep and primary settlement reduction. In conclusion, however, considering the very limited effect of stone columns with respect to creep settlement reduction, the difficulties faced by stonecolumn designers in making reliable predictions of creep settlement and the reduction in efficiency with respect to primary settlement reduction that occurs as a result of creep (Sexton and McCabe (2016) and Pugh in the discussion paper, Pugh et al. (2017)), it is considered that, for design purposes, stonecolumn groups in very soft clay should be assumed not to provide any reduction in creep settlement for cases where creep settlements are anticipated to be significant and/or dominant.

\section{Authors' reply}

The authors thank the discusser for supporting their numerically based empirical design method in the context of their field experience. There are now a number of independent contributions to their understanding of how stone columns impact on creep settlements - physical modelling by Moorhead (2013), numerical modelling by Sexton and McCabe (2013, 2016), Sexton et al. (2016, 2017) and field observations by 


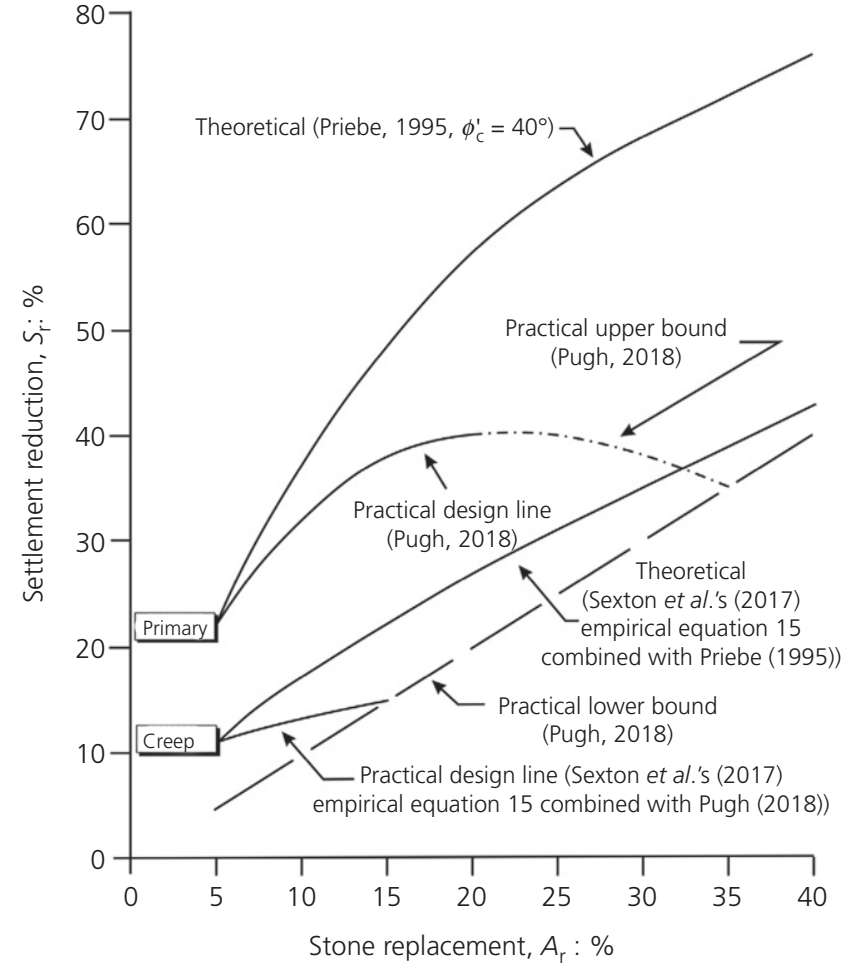

Figure 23. Primary and creep settlement reduction in theory and practice for stone-column groups installed in very soft clay

Pugh (2017) - all suggesting that the settlement improvement achievable for creep falls short of that achievable for primary consolidation. However, rather than assume conservatively that stone columns provide no improvement to creep settlements, the authors advise that the findings arising from recent modelling are explored further through controlled full-scale field trials at a suitable soft soil site where long-term settlement monitoring is possible. Such field testing could also offer some insight into other equally complex issues such as small group behaviour, particularly important given that empirical/ theoretical design methods relate to the unit cell scenario, representing an infinite grid of stone columns. Small groups have been modelled by Killeen and McCabe (2014) and McCabe and Killeen (2017), but field validation is needed.

The new empirical design method essentially provides a 'creep multiplier' on the primary settlement improvement factor derived from a pre-existing method. In the discusser's Figure 23, the primary settlement improvement curve has been based on Priebe (1995) with a stone friction angle of $40^{\circ}$. A numerical parametric study by Sexton et al. (2014) has suggested that the formulations of Castro and Sagaseta (2009) and Pulko et al. (2011) are more robust than Priebe (1995) over a wide range of load levels, friction/dilatancy angles and coefficients of lateral earth pressure, and these methods should be used in preference in industry.

\section{REFERENCES}

Castro J and Sagaseta C (2009) Consolidation around stone columns. Influence of column deformation. International Journal of Numerical and Analytical Methods in Geomechanics 33(7): 851-877.

Killeen MM and McCabe BA (2014) Pad footings on soft clay supported by stone columns: a numerical study of factors influencing settlement performance. Soils and Foundations 54(4): 760-776, https://doi.org/10.1016/j.sandf.2014.06.011.

McCabe BA and Killeen MM (2017) Small stone column groups: mechanics of deformation at serviceability limit state. International Journal of Geomechanics 15(5): 04016114, https://doi.org/10.1061/ (ASCE)GM.1943-5622.0000700.

Moorhead MC (2013) Effectiveness of Granular Columns for Containing Settlement of Foundations Supported on Soft Clay. PhD thesis, The Queen's University, Belfast, Ireland.

Priebe HJ (1995) The design of vibro replacement. Ground Engineering 28(10): $31-37$.

Pugh RS (2017) Settlement of floor slabs on stone columns in very soft clays. Proceedings of the Institution of Civil Engineers - Geotechnical Engineering 170(1): 16-26, https://doi.org/10.1680/jgeen.15.00150.

Pugh RS (2018) Briefing: efficiency of stone-column groups installed in very soft clays. Proceedings of the Institution of Civil Engineers - Geotechnical Engineering 171(2): 104-108, https://doi.org/10.1680/jgeen.17.00214.

Pugh RS, McCabe BA and Sexton BG (2017) Discussion: settlement of floor slabs on stone columns in very soft clays. Proceedings of the Institution of Civil Engineers - Geotechnical Engineering 170(5): 474 475, https://doi.org/10.1680/jgeen.17.00045.

Pulko B, Majes B and Logar J (2011) Geosynthetic-encased stone columns: analytical calculation model. Geotextiles and Geomembranes 29(1): 29-39.

Sexton BG and McCabe BA (2013) Numerical predictions of improvement to primary and creep settlements offered by granular columns. Acta Geotechnica 8(4): 447-464, https://doi.org/ 10.1007/s11440-012-0205-4.

Sexton BG, McCabe BA and Castro J (2014) Appraising stone column prediction methods using finite element analyses. Acta Geotechnica 9(6): 993-1011.

Sexton BG and McCabe BA (2016) Stone column effectiveness in soils with creep: a numerical study. Geomechanics and Geoengineering 11(4): 259-269, https://doi.org/10.1080/17486025.2016.1151556.

Sexton BG, McCabe BA, Karstunen M and Sivasithamparam N (2016) Stone column settlement performance in structured anisotropic clays: the influence of creep. Journal of Rock Mechanics and Geotechnical Engineering 8(5): 672-688, https:/doi.org/10.1016/ j.jrmge.2016.05.004.

Sexton BG, Sivakumar V and McCabe BA (2017) Creep improvement factors for vibro-replacement design. Proceedings of the Institution of Civil Engineers - Ground Improvement 170(1): 35-56, https://doi.org/10.1680/jgrim.16.00029. 